\title{
Methotrexate-loaded multifunctional nanoparticles with near-infrared irradiation for the treatment of rheumatoid arthritis
}

You-Jung Ha ${ }^{1 \dagger}$, Sun-Mi Lee ${ }^{2 \dagger}$, Chin Hee Mun ${ }^{1}$, Hyung Joon Kim², Yonghee Bae ${ }^{3}$, Ji-Hee Lim ${ }^{1}$, Kyu-Hyung Park', Soo-Kon Lee ${ }^{1}$, Kyung-Hwa Yoo ${ }^{2,3^{*}}$ and Yong-Beom Park ${ }^{1 *}$

\begin{abstract}
Backgrounds: Despite the advances of rheumatoid arthritis (RA) therapeutics, several patients do not receive adequate treatment due to the toxicity and/or insufficient response of drugs. The aim of this study is to design photothermally controlled drug release from multifunctional nanoparticles (MNPs) at a near-infrared (NIR) irradiated site to improve therapeutic efficacy for RA and reduce side effects.

Methods: Au film was deposited onto methotrexate (MTX)-loaded poly(ethylene glycol)-poly(lactic-co-glycolic acid) (PLGA) nanoparticles, resulting in MTX-loaded MNPs. The synergistic effects of MTX-loaded MNPs with NIR irradiation were investigated using RA fibroblast-like synoviocytes (FLSS) and collagen-induced arthritis (CIA) mice.

Results: Upon NIR irradiation, NIR resonance of the Au half-shell generated heat locally, accelerating MTX release from PLGA nanoparticles. In vivo NIR images of MTX-loaded MNPs indicated effective delivery of the MNPs to the inflamed joints. Moreover, in collagen-induced arthritis mice, MTX-loaded MNPs containing 1/1400 of MTX solution (repeated-dose administration) had therapeutic effects comparable to conventional treatment with MTX solution. In vitro experiments showed higher therapeutic efficacy of MTX-loaded MNPs with NIR irradiation than that of chemotherapy alone.

Conclusions: A combination therapy of MTX-loaded MNP and NIR irradiation showed durable and good treatment efficacy for the suppression of arthritis in a single administration of small dose of MTX. Our results demonstrate that the treatment modality using drug-loaded MNP with NIR irradiation may be a promising therapeutic strategy for the treatment of RA and allow in vivo NIR optical imaging.
\end{abstract}

Keywords: Rheumatoid arthritis, Multifunctional nanoparticle, Photothermally controlled drug delivery, Methotrexate

\footnotetext{
*Correspondence: khyoo@yonsei.ac.kr; yongbpark@yuhs.ac

†You-Jung Ha and Sun-Mi Lee contributed equally to this work.

${ }^{2}$ Nanomedical Graduate Program, Yonsei University, Seoul, Republic of Korea

'Division of Rheumatology, Department of Internal Medicine, Institute for

Immunology and Immunologic Diseases, Yonsei University College of

Medicine, 50, Yonsei-ro, Seodaemun-gu, Seoul 03722, Republic of Korea

Full list of author information is available at the end of the article
}

(c) The Author(s). 2020 Open Access This article is licensed under a Creative Commons Attribution 4.0 International License, which permits use, sharing, adaptation, distribution and reproduction in any medium or format, as long as you give appropriate credit to the original author(s) and the source, provide a link to the Creative Commons licence, and indicate if changes were made. The images or other third party material in this article are included in the article's Creative Commons licence, unless indicated otherwise in a credit line to the material. If material is not included in the article's Creative Commons licence and your intended use is not permitted by statutory regulation or exceeds the permitted use, you will need to obtain permission directly from the copyright holder. To view a copy of this licence, visit http://creativecommons.org/licenses/by/4.0/ The Creative Commons Public Domain Dedication waiver (http://creativecommons.org/publicdomain/zero/1.0/) applies to the data made available in this article, unless otherwise stated in a credit line to the data. 


\section{Background}

Rheumatoid arthritis (RA) is a chronic inflammatory disease characterized by synovial hyperplasia and bony erosion, leading to bone destruction and disability [1]. The mainstay of RA treatment is the administration of disease-modifying anti-rheumatic drugs (DMARDs) aimed at improving inflammation and retarding disease progression [2]. Methotrexate (MTX) is a structural analogue of folic acid that can competitively inhibit the binding of dihydrofolic acid to the enzyme dihydrofolate reductase, consequently inhibiting DNA formation and cell proliferation. MTX has been widely used as a DMARD and exhibits excellent efficacy and an acceptable toxicity profile $[3,4]$. However, approximately $30 \%$ of RA patients cannot tolerate MTX because of its side effects, which include nausea, vomiting, stomatitis, hepatotoxicity, and bone marrow suppression [5]. The adverse effects of MTX are dose-dependent, so several delivery systems using nanoparticles (NPs), liposomes, microspheres, and different polymers have been suggested to improve the delivery of MTX [6].

Previously, we reported the use of multifunctional nanoparticles (MNPs) consisting of arginine-glycineaspartic acid (RGD)-conjugated MTX-loaded poly(DLlactic-co-glycolic acid; PLGA) Au half-shell NPs (RGDMTX-PLGA-Au H-S NPs) [7]. RGD binds to a variety of integrins that are highly expressed in RA synovial tissue, so it serves as a targeting moiety for inflammatory sites, leading to enhanced drug delivery into inflamed synovium $[8,9]$. However, the use of RGD may hinder clinical applications because of high costs and regulatory hurdles. Hence, we synthesized MTX-loaded MNPs without RGD and evaluated their passive targeting and therapeutic efficacy using a collagen-induced arthritis (CIA) mouse model. To confirm a synergistic effect of MTX-loaded MNPs combined with near-infrared (NIR) irradiation, we also investigated the therapeutic efficacy of MTX-loaded MNPs combined with NIR irradiation in RA fibroblast-like synoviocytes (FLSs).

\section{Methods}

\section{Materials}

PLGA (L:G molar ratio $=50: 50 ; M W=20,000$ ) was purchased from Wako (Japan). MTX and Pluronic F-127 were purchased from Sigma-Aldrich Chemical Co. (St. Louis, MO, USA). Thiol-terminated methoxypoly(ethylene glycol) $\left(\mathrm{SH}-\mathrm{PEG}-\mathrm{OCH}_{3}, \mathrm{MW}=5000\right)$ was purchased from Creative PEG-Works (USA).

\section{Synthesis and characteristics of MTX-loaded MNPs}

The MTX-loaded PLGA NPs were prepared as reported previously [10, 11]. Briefly, MTX (6 mg, Sigma-Aldrich) and PLGA $(200 \mathrm{mg})$ were dissolved in dichloroethane $(20 \mathrm{ml})$, which was stirred for $24 \mathrm{~h}$ at room temperature under nitrogen atmosphere. Then, the organic solution was slowly added drop-wise into distilled water $(200 \mathrm{ml})$ containing Pluronic F-127 (2 mg) under magnetic stirring. The NPs were formed immediately, and the solvent was removed by overnight evaporation at room temperature. Then, the MTX-loaded PLGA NPs were collected by centrifugation and re-dispersed in distilled water $(5 \mathrm{ml})$ by sonication. Au film $(15 \mathrm{~nm})$ was deposited onto an MTX-loaded PLGA NP monolayer prepared on a Si substrate using a thermal evaporator. To stabilize the NPs under in vivo conditions, Au-deposited MTX-loaded PLGA NPs were released from the substrate surface by sonication into $1 \mathrm{wt} \%$ thiol-terminated methoxy-PEG solutions and then collected by centrifugation, resulting in MTX-loaded MNPs with an Au halfshell structure (Fig. 1a). The Au half-shell structure of MTX-loaded MNPs was confirmed using a transmission electron microscope (TEM) (inset in Fig. 1b). The MTX loading efficiency, defined as the ratio of the actual mass of the MTX-loaded MNPs relative to the total mass of the MTX-unloaded MNPs, was estimated to be approximately $2.5 \%$. Using dynamic light scattering, the MNPs were determined to be $100-115 \mathrm{~nm}$ in diameter (Additional file 1). The ultraviolet-visible/NIR absorption spectrum of the MTX-loaded MNPs exhibited a pronounced peak at approximately $810 \mathrm{~nm}$ due to the $\mathrm{Au}$ half-shells (Fig. 1b), suggesting that MTX-loaded MNPs can be used for photothermal treatment and in vivo NIR absorbance imaging.

\section{Immunofluorescence}

Rhodamine-loaded MNPs were synthesized using a procedure similar to that for the MTX-loaded MNPs. A total of $200 \mu \mathrm{l}$ of rhodamine solution was injected into the two hind foot pad of CIA mice. The same volume of rhodamine-loaded MNP solution $(1 \mathrm{mg} / \mathrm{ml}$ dispersed in phosphate-buffered saline [PBS]) was injected into the four hind foot pad of other CIA mice. Subsequently, the limbs of two mice were exposed to NIR at $1.96 \mathrm{~W} / \mathrm{cm}^{2}$, while the other two mice were unexposed. The amount of rhodamine in rhodamine-loaded MNPs was about $1 /$ 1200 of rhodamine solution. One mouse from each group was sacrificed $1 \mathrm{~h}$ after injection, and the other was sacrificed $24 \mathrm{~h}$ after injection. All samples were counterstained with 4', 6-diamidino-2-phenylindole (DAPI). The paws were embedded in OCT compound and horizontally sectioned.

\section{Biodistribution}

MTX-loaded MNPs $(200 \mu \mathrm{l}, 1 \mathrm{mg} / \mathrm{ml}$ dispersed in PBS) were administered intravenously (IV) into CIA mice (total $n=9$ ). The mice were sacrificed 1,3 , or 28 days after injection ( $n=3$ at each point), and the major organs (liver, heart, spleen, kidney, and lung) and joints 
a

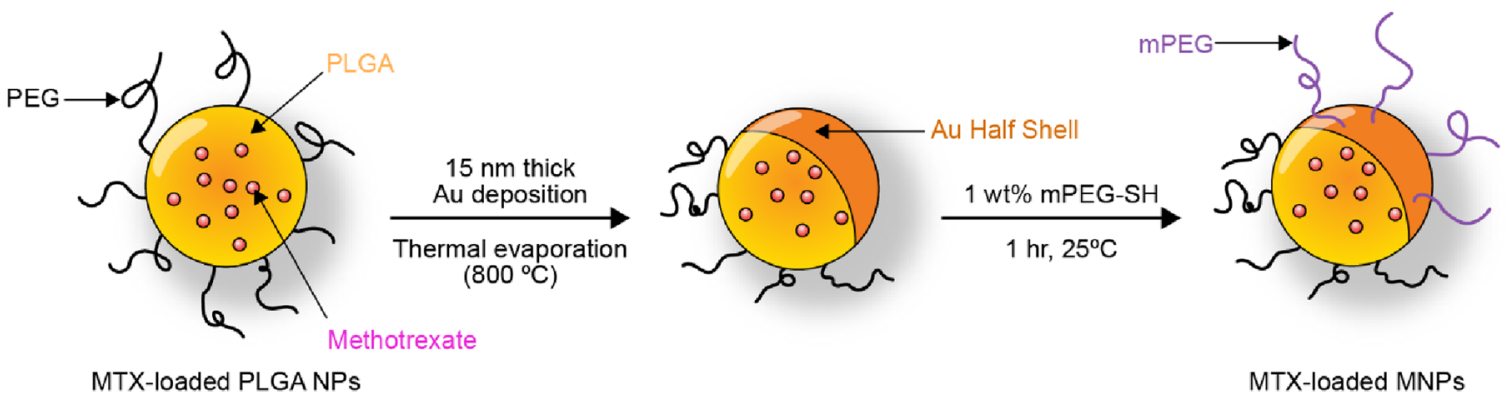

b

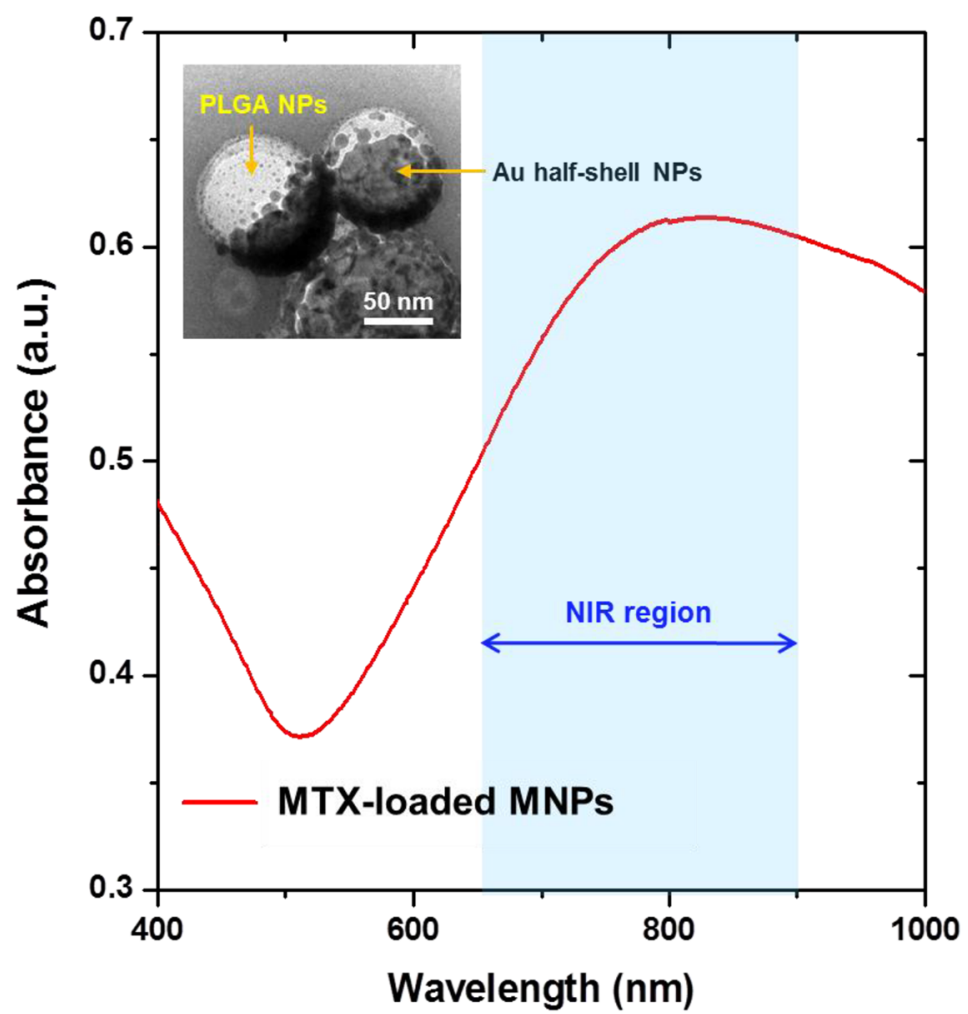

Fig. 1 Fabrication and characteristics of MTX-loaded MNPs. a Schematic fabrication process of MTX-loaded MNPs. b TEM images of 100-115-nm MNPs with Au half-shell (left upper corner) and NIR absorption spectrum of the MTX-loaded MNPs

were removed from each mouse. Tissue samples were placed in a mixed acid matrix of aqua regia and heated overnight at $80-90^{\circ} \mathrm{C}$. After additional heating at $130-140{ }^{\circ} \mathrm{C}$ for $2 \mathrm{~h}$, the organic compounds were completely removed and only ionized $\mathrm{Au}$ remained. This residue was dissolved in $1 \mathrm{ml}$ of 0.5 $\mathrm{M} \mathrm{HCl}$ and analyzed using an inductively coupled plasma mass spectrometer (ICP-MS, Agilent 7500C).

\section{Ex vivo NIR imaging}

MTX-loaded MNPs (200 $\mu \mathrm{l}, 1 \mathrm{mg} / \mathrm{ml}$ dispersed in PBS) were injected intravenously into the CIA mice. The mice were sacrificed 1,3 , or 28 days after injection, and the major organs (liver, heart, spleen, kidney, and lung) were removed from each mouse. NIR absorbance images were obtained using an eXplore Optix System (Advanced Research Technologies Inc., Montreal, Canada) with the black color denoting the strongest absorption. Absorbance at $710 \sim 750 \mathrm{~nm}$ was detected with a fast photomultiplier tube (Hamamatsu, Japan) and a time-correlated single photon counting system (Becker and Hickl GmbH, Berlin, Germany). All data were calculated using the region-ofinterest function of the analytical workstation software. 


\section{$\mathrm{CIA}$ induction and assessment}

All animal experiments were approved by and conducted in accordance with the regulations of the Institutional Animal Care and Use Committee of Yonsei University, Seoul, Korea. All mice were maintained in a specific pathogen-free facility. First, an intradermal injection of $200 \mu \mathrm{g}$ bovine type II collagen (CII, Chondrex, Redmond, WA, USA) emulsified in $200 \mu \mathrm{g}$ of complete Freund's adjuvant (Chondrex, Redmond, WA, USA) was administered in the base of the tail of male DBA/1J mice (8 weeks old, Central Lab Animal, Inc., Seoul, Korea) to induce arthritis. Next, a booster intradermal injection of $100 \mu \mathrm{g}$ bovine CII in incomplete Freund's was given to mice at 14 days after the primary immunization. Mice were monitored twice a week for clinical assessment of arthritis. Disease severity was assessed in each limb according to a previously described scoring system (score $0-4)$ [12]. The scores for each limb were added, giving a maximum score of 16 per animal. Arthritis scoring was performed by two independent observers. Paw thickness was also measured twice a week with a Vernier caliper.

Upon arthritis development (arthritis score of 8-10), mice were randomly assigned to each treatment group $(n=5)$ at 4 weeks after the second booster injection, as described in Table 1. Briefly, saline (G1, positive control), low-dose MTX (G3), or PLGA-MNPs (G4-6) were once administered via intravenous tail injection. MTX-unloaded MNPs were given to G4, whereas MTX-loaded MNPs were given to G5 and G6. G4 and G6 were also exposed to $1.96 \mathrm{~W} / \mathrm{cm}^{2}$ NIR light for $10 \mathrm{~min}$ the next day after MNP injection. A high-dose MTX solution group (G2, representing conventional MTX treatment) received intraperitoneal injection of $35 \mathrm{mg} / \mathrm{kg}$ MTX twice a week, weekly till sacrifice.

\section{Histological examination}

Mice were anesthetized and sacrificed on day 28 after treatment. The front and hind paws (including carpus, tarsus, and knee joints) were removed, and the skin from the ends of the digits was removed as well. Samples were fixed, decalcified, and embedded in paraffin. Tissue sections were prepared and stained with hematoxylin and eosin stain. The histological scores for changes in synovial inflammation, bone erosion, and proliferation were evaluated as previously described [13]. All histological analyses were evaluated blindly by three independent examiners.

\section{Measurement of immunoglobulin $\mathrm{G}$ antibodies to type II collagen and serum cytokines}

Serum was collected from animals in each group of mice and stored at $-70{ }^{\circ} \mathrm{C}$ until assayed. The levels of serum anti-CII immunoglobulin G (IgG) were determined using a commercially available ELISA kit (\#6018, Chondrex, Redmond, WA, USA) according to the manufacturer's instructions. Serum levels of inflammatory murine cytokines interleukin (IL)-6, IL-12p70, and tumor necrosis factor (TNF)- $\alpha$ were determined using commercial mouse IL-6, IL-12p70, and TNF- $\alpha$ enzymelinked immunosorbent assay (ELISA) kits (BD Biosciences, USA). Each sample was assayed in duplicate.

\section{FLS preparation and culturing}

Synovial tissue was obtained from three RA patients who underwent knee joint replacement surgery at Severance Hospital, Yonsei University College of Medicine, Seoul, Korea. The study was approved by the ethics committee of our institution (IRB No. 4-2019-0683), and

Table 1 Treatments applied to RA-FLS or CIA mice for comparative study of therapeutic efficacy

\begin{tabular}{|c|c|c|c|c|c|c|c|}
\hline \multirow[t]{2}{*}{ Group } & \multirow[t]{2}{*}{ Treated content } & \multicolumn{2}{|l|}{ In vivo } & \multirow[t]{2}{*}{ Group } & \multirow[t]{2}{*}{ Treated content } & \multicolumn{2}{|l|}{ In vitro } \\
\hline & & $\begin{array}{l}\text { MTX dosage }(\mathrm{mg} / \mathrm{kg}) \text { and } \\
\text { administration route }\end{array}$ & $\begin{array}{l}\text { NIR light (W/ } \\
\left(\mathrm{cm}^{2}\right)^{\mathrm{b}}\end{array}$ & & & $\begin{array}{l}\text { MTX concentration } \\
(\mu \mathrm{M})^{c}\end{array}$ & $\begin{array}{l}\text { NIR light (W/ } \\
\left(\mathrm{cm}^{2}\right)^{\mathrm{d}}\end{array}$ \\
\hline $\begin{array}{l}\text { Group } \\
1\end{array}$ & Saline & - & - & $\begin{array}{l}\text { Group } \\
1\end{array}$ & Saline & - & - \\
\hline $\begin{array}{l}\text { Group } \\
2\end{array}$ & $\begin{array}{l}\text { MTX solution (high } \\
\text { dose) }\end{array}$ & $35 \times 8$ times, $I P$ & - & $\begin{array}{l}\text { Group } \\
2\end{array}$ & $\begin{array}{l}\text { MTX solution (low } \\
\text { dose) }\end{array}$ & 0.13 & - \\
\hline $\begin{array}{l}\text { Group } \\
3\end{array}$ & $\begin{array}{l}\text { MTX solution (low } \\
\text { dose) }\end{array}$ & $0.2 \times 1$ time, IV & - & $\begin{array}{l}\text { Group } \\
3\end{array}$ & $\begin{array}{l}\text { MTX solution (high } \\
\text { dose) }\end{array}$ & 30 & - \\
\hline $\begin{array}{l}\text { Group } \\
4\end{array}$ & $\begin{array}{l}\text { MTX-unloaded } \\
\text { MNPs }\end{array}$ &,$- I V$ & 1.96 & $\begin{array}{l}\text { Group } \\
4\end{array}$ & $\begin{array}{l}\text { MTX-unloaded } \\
\text { MNPs }\end{array}$ & - & - \\
\hline $\begin{array}{l}\text { Group } \\
5\end{array}$ & MTX-loaded MNPs & $0.2, \mathrm{IV}$ & - & $\begin{array}{l}\text { Group } \\
5\end{array}$ & $\begin{array}{l}\text { MTX-unloaded } \\
\text { MNPs + NIR }\end{array}$ & - & 0.38 \\
\hline \multirow[t]{2}{*}{$\begin{array}{l}\text { Group } \\
6\end{array}$} & MTX-loaded MNPs & $0.2, \mathrm{IV}$ & 1.96 & $\begin{array}{l}\text { Group } \\
6\end{array}$ & MTX-loaded MNPs & 0.13 & - \\
\hline & & & & $\begin{array}{l}\text { Group } \\
7\end{array}$ & $\begin{array}{l}\text { MTX-loaded MNPs + } \\
\text { NIR }\end{array}$ & 0.13 & 0.38 \\
\hline
\end{tabular}

${ }^{\mathrm{a}}$ Treated volume of MNPs; $30 \mu \mathrm{l} / \mathrm{ml}$, MNP concentration of $1 \mathrm{mg} / \mathrm{ml}{ }^{\mathrm{b}}$ The arthritic limb was exposed to NIR light for $10 \mathrm{~min}$ using a laser diode $(\lambda=808 \mathrm{~nm}) 24 \mathrm{~h}$ post-injection. ${ }^{\mathrm{C}}$ Treated volume of MNPs; $30 \mu \mathrm{l} / \mathrm{ml}$, MNP concentration of $1 \mathrm{mg} / \mathrm{ml}$. ${ }^{\mathrm{d}}$ The RA-FLS was exposed to NIR light for $10 \mathrm{~min}$ using a laser diode $(\lambda=808$ $\mathrm{nm}) 24 \mathrm{~h}$ post-incubation 
written informed consent was obtained from all participants. All patients satisfied the 1987 revised American College of Rheumatology classification criteria for RA [14]. FLS cells were isolated from 3 different donors and cultured as previously described [15]. Cells obtained from passages 4 to 8 were seeded onto 12 -well plates at a density of $2 \times 10^{4}$ cells/well in Dulbecco's modified Eagle's medium supplemented with $10 \%$ fetal bovine serum (Gibco BRL, Grand Island, NY, USA), $2 \mathrm{~m} M$ L-glutamine, $100 \mathrm{units} / \mathrm{ml}$ of penicillin, and $100 \mathrm{~g} / \mathrm{ml}$ of streptomycin. The seeded cells were incubated at $37^{\circ} \mathrm{C}$.

\section{Apoptotic cell assay}

A fluorescein isothiocyanate (FITC) Annexin V Apoptosis Detection kit (BD Biosciences, San Diego, CA, USA) was used to quantify the apoptotic cells of cultured FLS, according to the manufacturer's protocol. Cells were treated with MTX solution $(0.13$ or $30 \mu \mathrm{M})$, MTX-unloaded MNPs with or without NIR irradiation, and MTX-loaded MNPs $(0.13 \mu \mathrm{M}$ of MTX) with or without NIR irradiation and incubated at $37^{\circ} \mathrm{C}$ for $48 \mathrm{~h}$. NIR irradiation was conducted $24 \mathrm{~h}$ after treatment at $0.38 \mathrm{~W} / \mathrm{cm}^{2}$ for $10 \mathrm{~min}$. Treated cells were harvested by centrifugation and washed in cold PBS. Annexin V-FITC and propidium iodide (PI) were added to $400 \mu \mathrm{l}$ of cells. Following a 15-min incubation in the dark at room temperature, the stained cells were immediately analyzed by flow cytometry (FACS Calibur, BD). A minimum of 10,000 events were collected and analyzed using FlowJo software (TreeStar, Inc., Ashland, OR, USA). Annexin $\mathrm{V}$-positive and PI-negative cells were defined as early apoptotic cells, and PI-positive cells were defined as late apoptotic or necrotic cells.

\section{Statistical analyses}

All statistical analyses were conducted using IBM SPSS Statistics, version 20 (SPSS Inc., Chicago, IL, USA). Data are shown as means \pm standard deviation. Statistical analyses of group differences were performed using the Mann-Whitney $U$ test or ANOVA followed by Tukey's method. For all analyses, $P$ values $<0.05$ were considered statistically significant.

\section{Results}

\section{Photothermally controlled drug release}

To check local photothermal effect on drug release from MNPs, we injected $200 \mu \mathrm{l}$ of rhodamine solution into a CIA mouse and acquired the optical images from the tissues that were sectioned from the inflamed paws at $1 \mathrm{~h}$ and $24 \mathrm{~h}$ after injection (Fig. 2 left panel). Rhodamine was prominently detected at $1 \mathrm{~h}$, but not at $24 \mathrm{~h}$, suggesting that rhodamine was rapidly cleared from the body. Next, we administered $200 \mu \mathrm{l}$ of rhodamine-loaded MNPs (1 mg/ml dispersed in PBS) into the arthritic hind food pad of CIA mice. Figure 2 shows the optical images obtained from the inflamed paws unexposed (mid panel) and exposed to NIR light (right panel) for $10 \mathrm{~min}$ at $1.96 \mathrm{~W} / \mathrm{cm}^{2}$ after treatments of rhodamine-loaded MNPs, respectively. Both mice showed rhodamine at 24 $\mathrm{h}$, indicating that rhodamine-loaded MNPs were accumulated in the inflamed paw until $24 \mathrm{~h}$. However, compared to the inflamed paw unexposed to NIR, the inflamed paw exposed to NIR yielded a higher intensity of rhodamine at 1 and $24 \mathrm{~h}$ due to an enhanced release rate of rhodamine caused by NIR irradiation.

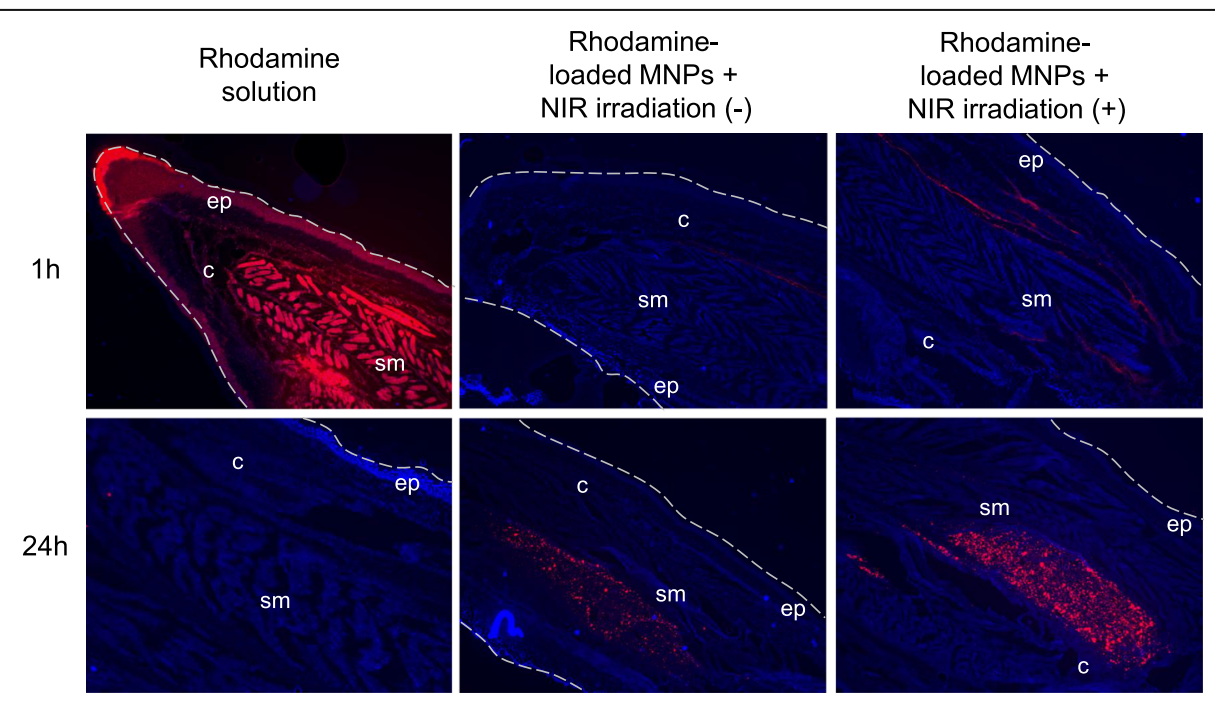

Fig. 2 The local drug release effects of NIR irradiation on MNPs. The sections of the inflamed paw were examined at $1 \mathrm{~h}$ and $24 \mathrm{~h}$ after local administration of rhodamine solution and rhodamine-loaded MNPs without/with NIR irradiation. Sections were counterstained by DAPI (blue). Dotted lines indicate the boundaries of paws. c, connective tissue; ep, epidermis; sm, skeletal muscle. Original magnification $\times 100$ 


\section{In vivo delivery and distribution of MNPs}

To determine whether MTX-loaded MNPs are delivered to and accumulated in an inflamed region, $200 \mu \mathrm{l}$ of MTX-loaded MNP solution (1 mg/ml dispersed in PBS) was administrated IV into a CIA mouse with an inflamed right paw and non-inflamed left paw. Time-lapse in vivo NIR absorbance images measured at $24 \mathrm{~h}$ after IV injection revealed that absorbance intensity $\geq 4 \times 10^{3}$ a.u. (blue in Fig. 3a) increased over time in the inflamed paw whereas a change in the absorbance intensity was not apparent in the non-inflamed paw (Fig. 3a). These results indicated that the MTX-loaded MNPs were preferentially delivered to and accumulated in the inflamed paw.

In addition, the distribution of injected MTX-loaded MNPs (200 $\mu \mathrm{l}, 1 \mathrm{mg} / \mathrm{ml}$ dispersed in PBS) in major organs and inflamed joint was measured by ICP-MS at 1 , 3 , and 28 days following the IV injection (Additional file 2a). The MTX-loaded MNPs accumulated efficiently in the inflamed joint and demonstrated extended retention until 3 days; $0.16 \mu \mathrm{g}$ of Au was found in the inflamed joints of CIA mice treated with MTXloaded MNPs $24 \mathrm{~h}$ post administration, corresponding to $0.7 \%$ of the injected MTX-loaded MNPs. MTX-loaded

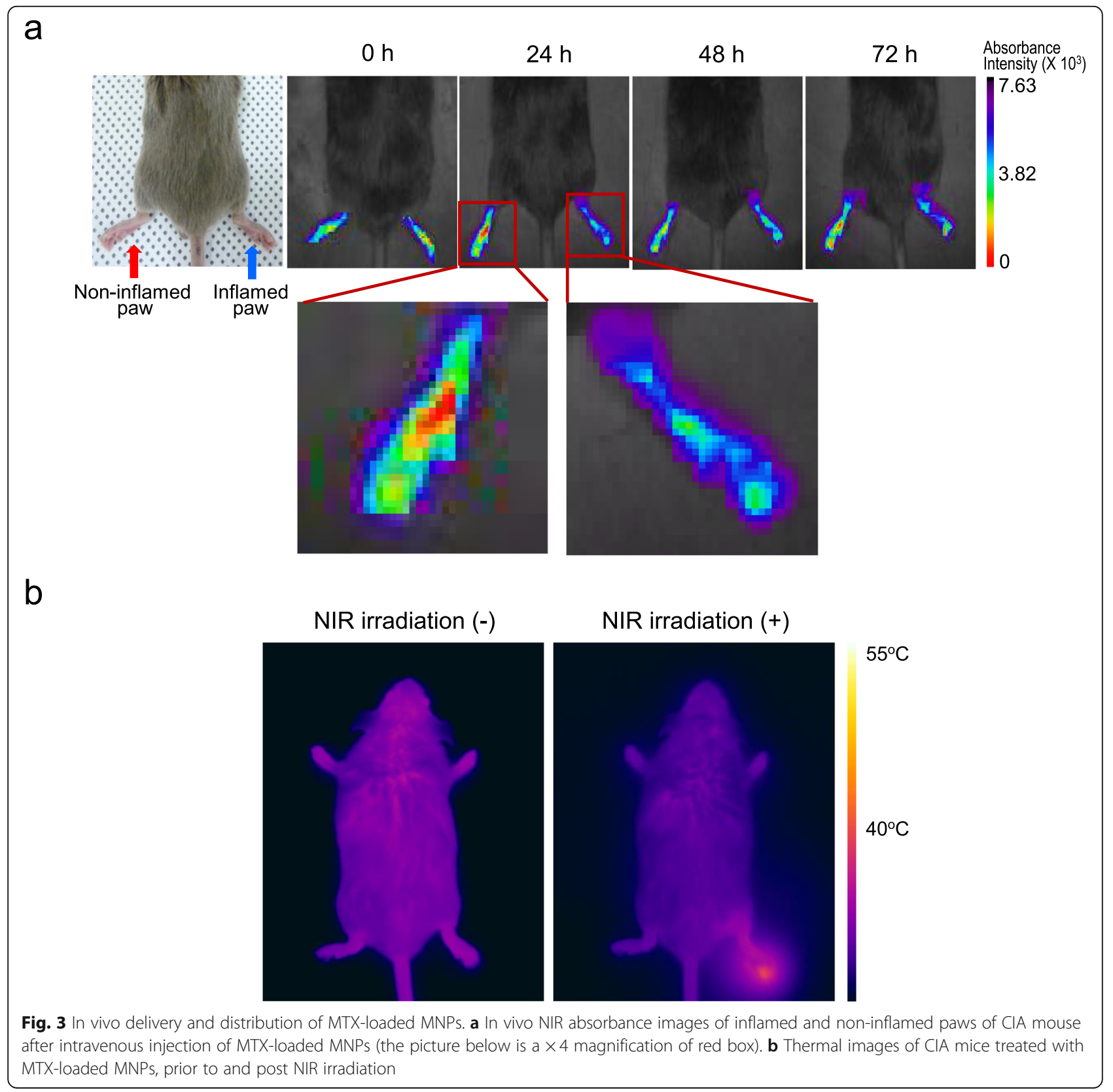


MNPs were also taken up by the liver, lung, and spleen, with lesser accumulation in the kidney and heart. However, the amount of MTX-loaded MNPs in these organs was significantly reduced at 28 days. We also measured ex vivo NIR absorbance images of the injected MNPs and found a biodistribution similar to the ICP-MS results (Additional file 2b).

The left panel of Fig. 3b shows a thermal image of a CIA mouse treated with $24 \mathrm{~h}$ post-injection MTXloaded MNPs $(200 \mu \mathrm{l})$ and unexposed to NIR light. The temperature was approximately $36^{\circ} \mathrm{C}$ throughout the entire body, corresponding to the body temperature of the mouse. However, when the inflamed paw was irradiated by NIR $\left(1.96 \mathrm{~W} / \mathrm{cm}^{2}\right)$ for $10 \mathrm{~min}$, the temperature increased to $43^{\circ} \mathrm{C}$ only in the irradiated paw, and no significant temperature increase was observed in the region that was not exposed to NIR (right panel in Fig. 3b). These findings indicate that heat can be directed to only the inflamed region using laser guidance.

\section{Comparisons of therapeutic efficacy in CIA mice}

To investigate the therapeutic efficacy of MTX-loaded MNPs, thirty CIA mice were evenly divided into six groups ( $n=5$ per group), as summarized in Table 1 . The timetable of CIA induction and applied treatment is described in Fig. 4a. Figure 4b shows the clinical index of these groups as a function of time. For a positive control, $35 \mathrm{mg} / \mathrm{kg}$ MTX solution was intraperitoneally administrated twice per week for 4 weeks, leading to a total MTX solution of $280 \mathrm{mg} / \mathrm{kg}$ (G2). The clinical index decreased from day 49, 1 week post treatment. G6 was treated with MTX-loaded MNPs $(0.2 \mathrm{mg} / \mathrm{kg}$ of MTX) and exposed to NIR light $\left(1.96 \mathrm{~W} / \mathrm{cm}^{2}\right)$ for $10 \mathrm{~min}$ at 1 day after MNP treatment. Despite a much lower MTX dosage for $\mathrm{G} 6(0.2 \mathrm{mg} / \mathrm{kg})$ than $\mathrm{G} 2(280 \mathrm{mg} / \mathrm{kg})$, similar treatment efficacy was obtained. However, when treated with $0.2 \mathrm{mg} / \mathrm{kg}$ MTX solution (G3) or MTX-unloaded MNPs with NIR irradiation (G4), arthritis was not ameliorated in mice although treatment with MTX-loaded MNPs without NIR irradiation (G5) led to a partial treatment only during the early period. These results demonstrate that chemo-photothermal treatment using MTX-loaded MNPs is a good way to maximize therapeutic efficacy and minimize dosage-related MTX side effects in the treatment of RA. It is well established that anti-CII antibody is involved in the pathogenesis of CIA [16]. Serological levels of CII-specific IgG were measured 4 weeks after treatment to determine whether the treatment was associated with a change in the humoral immune response to CII. As shown in Fig. 4c, the anti-CII IgG levels in the sera of G2-G6 mice were significantly reduced than those in G1 mice. Among them, the levels of serum anti-CII IgG decreased the most in G2 and G6.
Histopathological evaluation of the joint sections of untreated mice showed severe inflammatory cell infiltration, synovial hyperplasia, and bony erosion. These histopathological changes were significantly reduced in G2 and G6 mice. In contrast, no significant differences were observed in G3, G4, or G5 mice (Fig. 5a, b). To investigate whether MNPs could decrease serum levels of pro-inflammatory cytokines, we measured the levels of IL-6, IL-12p70, and TNF- $\alpha$ in the serum of CIA mice. Compared with untreated mice, the serum cytokine levels were significantly decreased in mice treated with $35 \mathrm{mg} / \mathrm{kg}$ MTX solution twice per week for 4 weeks (G2) and MTX-loaded MNPs with NIR irradiation (G6) (Fig. 5c). These results suggest that the therapeutic effect of MNPs with NIR irradiation is comparable to that of conventional MTX treatment.

\section{In vitro studies in RA-FLS with MTX-loaded MNPs}

To study the anti-arthritic effect of MTX-loaded MNPs and NIR irradiation in vitro, we divided RA-FLS cells into seven groups and treated them differently, as summarized in Table 1. G1 was a FLS control group. G2 and G3 were treated with MTX solution of $0.13 \mu \mathrm{M}$ and $30 \mu \mathrm{M}$, respectively. G4-G7 were prepared by culturing the cells with MTX-unloaded MNPs (G4 and G5) or MTX-loaded MNPs (MTX $0.13 \mu \mathrm{M}$; G6 and G7) for 1 day, followed by washing with PBS. After that, RA-FLS cells treated with MNPs were exposed to NIR for $10 \mathrm{~min}$ at $0.38 \mathrm{~W} / \mathrm{cm}^{2}$ in G5 and G7, and apoptotic cell death was evaluated using a FACS at $48 \mathrm{~h}$ after NIR irradiation (Fig. 6a). As expected, G2 yielded much less apoptotic cell death than G3 because of the lower MTX concentration. The apoptotic cell death in G4 tended to be increased than that in G1, but the differences were insignificant, implying that MTX-unloaded MNPs alone did not significantly affect apoptotic cell death. Adding NIR irradiation to MTX-unloaded MNPs (G5) and treatment of MTX-loaded MNPs without NIR irradiation (G6) significantly enhance apoptotic cell death. The combined treatment of MTX-loaded MNPs and NIR irradiation (G7) lead the greatest apoptotic cell death, although the dosage of MTX in G7 was only $1 / 230$ of that in G3. These results demonstrated a synergistic effect of MTX-loaded MNPs combined with NIR irradiation.

We also measured the cell viability of RA-FLS cells treated with MTX-unloaded MNPs and exposed to NIR light for $10 \mathrm{~min}$ at different powers to investigate the dependence of cell viability on temperature (Fig. 6b). At $0.82 \mathrm{~W} / \mathrm{cm}^{2}$, the temperature increased to $60^{\circ} \mathrm{C}$, and the cell viability was reduced to about $49 \%$ due to cell death. However, for the NIR power less than $0.53 \mathrm{~W} / \mathrm{cm}^{2}$, the cell viability remained higher than $88 \%$, indicating that cell viability was not much affected by NIR irradiation at low powers. 
a

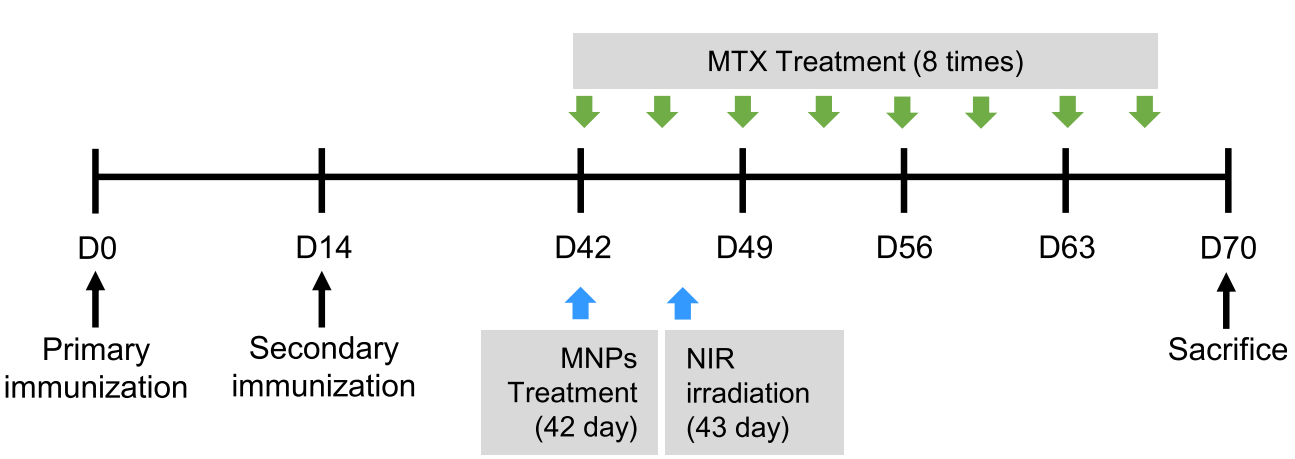

b

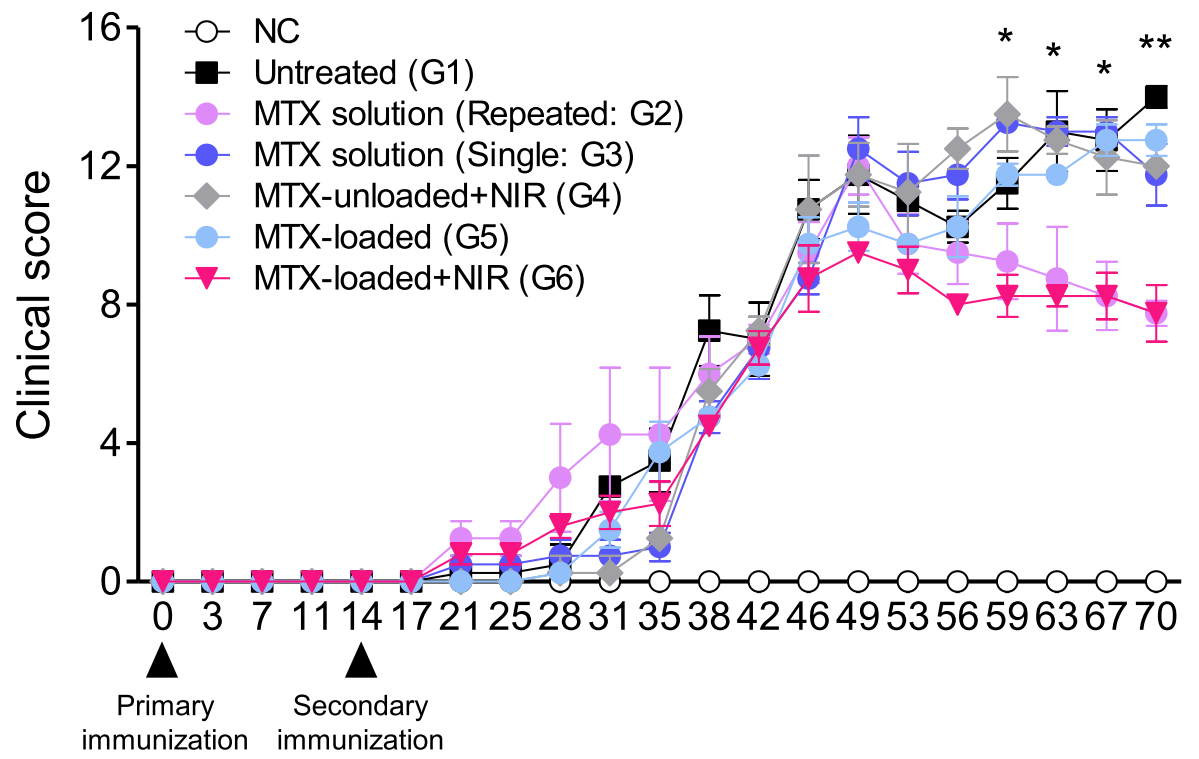

Days after $1^{\text {st }}$ immunization

C

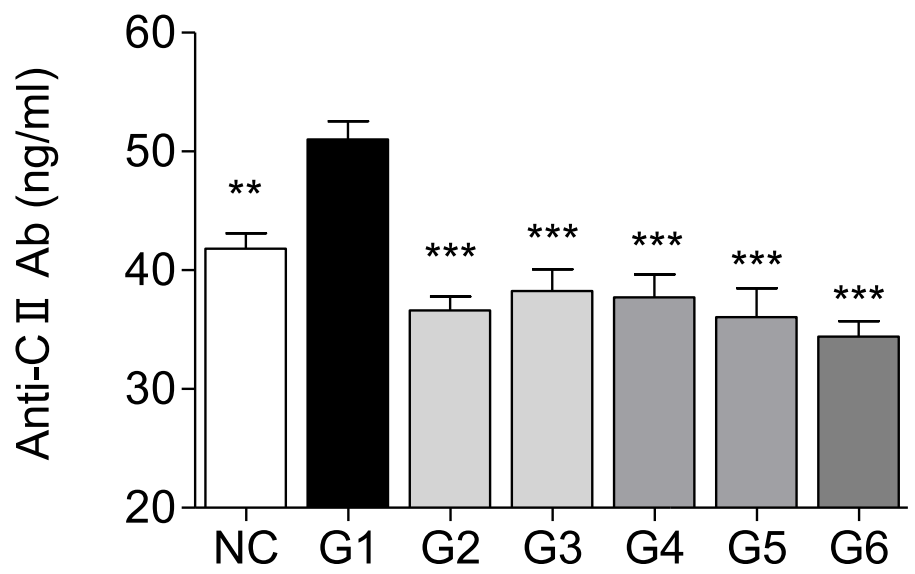

Fig. 4 (See legend on next page.) 
(See figure on previous page.)

Fig. 4 Comparative studies of therapeutic efficacy in CIA mice. a The schedule for CIA induction and treatment. b Severity of arthritis in CIA mice. NC, negative control; G1, PBS-treated; G2, 35 mg/kg MTX solution twice per week intraperitoneal; G3, 0.2 mg/kg MTX solution once IV; G4, MTXunloaded MNPs IV + NIR irradiation; G5, MTX-loaded MNPs IV; G6, MTX-loaded MNPs IV + NIR irradiation. Mean clinical scores were significantly decreased in G2 and G6 mice compared with untreated mice. c Changes in anti-collagen II lgG titers in mice of different treatment groups. Data are expressed as mean \pm SEM of 5 mice for duplicated serum samples. ${ }^{*} P<0.01,{ }^{* *} P<0.001$ vs. the untreated group (G1)

\section{Discussion}

We investigated the clinical potential of MTX-loaded MNPs with NIR irradiation for the treatment of RA. MTX-loaded MNPs showed more delivery to inflamed joints and induced sustained release, especially when irradiated with NIR. In vitro and in vivo studies using RA-FLSs and CIA mice confirmed photothermally controlled drug release and anti-arthritic effects of the combination therapy of MTX-loaded MNPs and NIR irradiation.

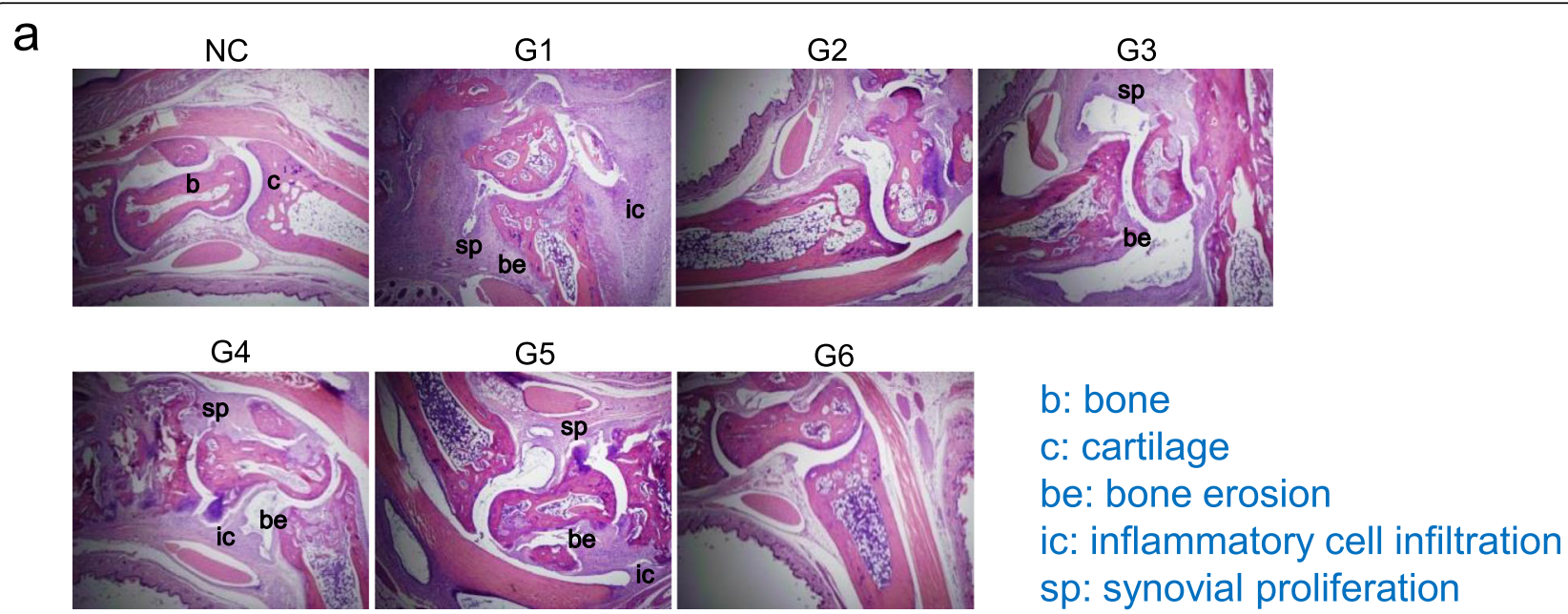

b
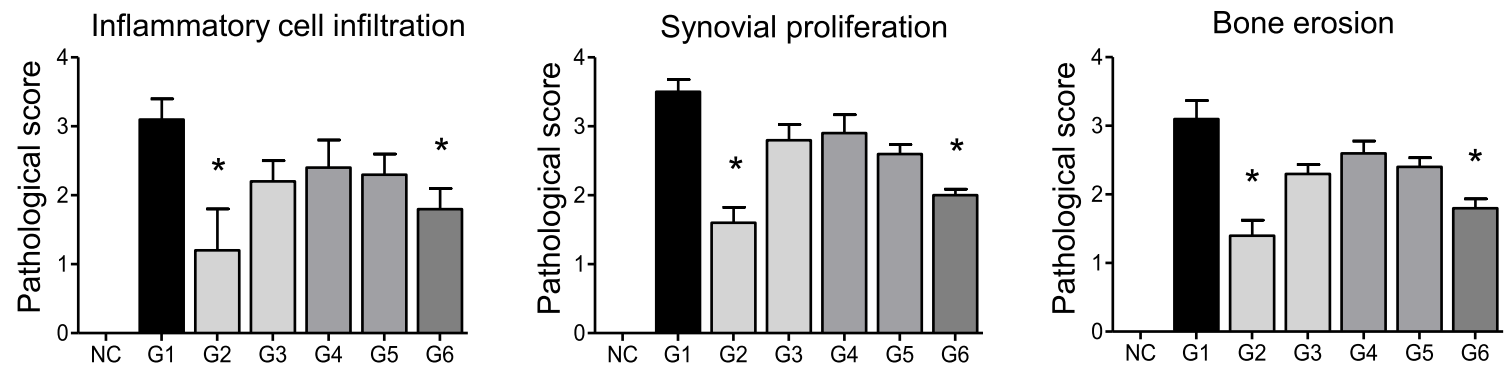

C
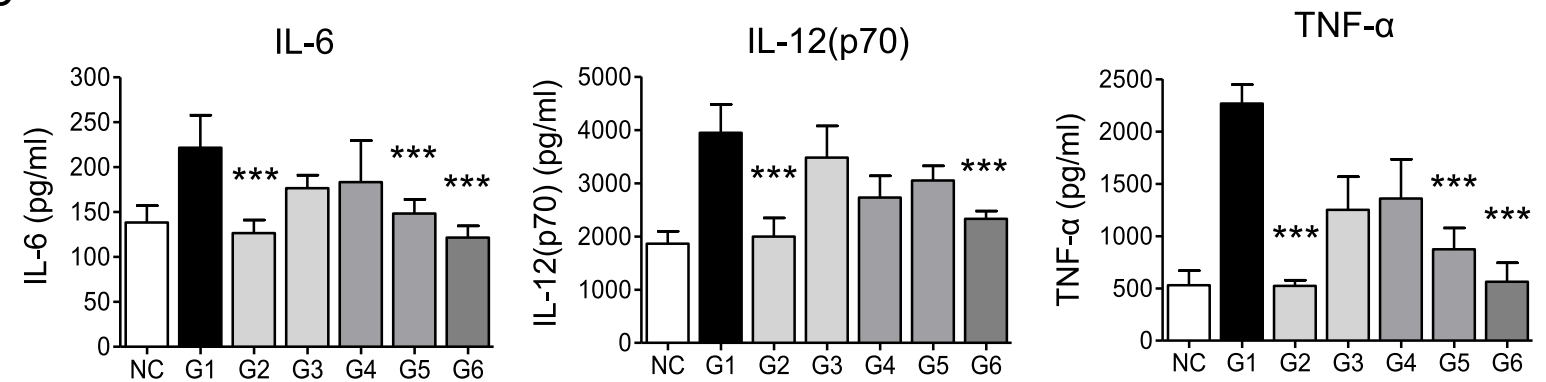

Fig. 5 MTX-loaded MNPs with NIR irradiation ameliorate histopathologic changes and suppress pro-inflammatory cytokines in CIA mice. a Histological findings of ankle joints, original magnifications $\times 100$. b, bone; $c$, cartilage; $b$, bone erosion; ic, inflammatory cell infiltration; $s p$, synovial proliferation. b Semiquantitative analyses of histological changes, ${ }^{*} P<0.01$ vs. the untreated group (G1). c Cytokine assays by ELISA. ${ }^{*} P<$ $0.05,{ }^{* *} P<0.01,{ }^{* * *} P<0.001$ vs. the untreated group $(\mathrm{G} 1)$. Values are expressed as mean \pm SEM of five mice 


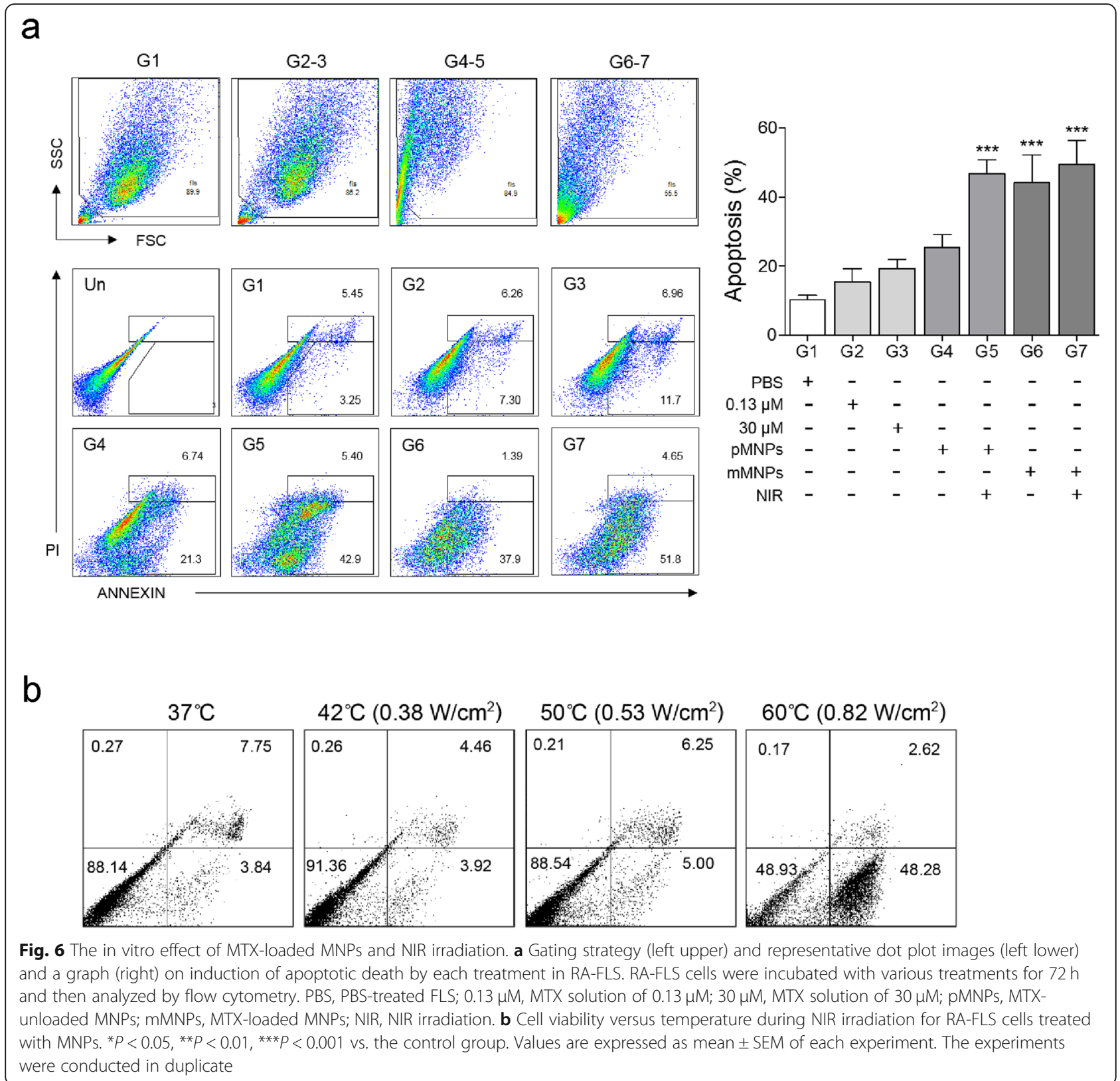

Although MTX is one of the most effective drugs for the management of RA, some limitations restrict the use of MTX. The pharmacokinetics of oral low-dose MTX appears to be variable and largely unpredictable even in patients with normal renal and hepatic function [17]. MTX has also several side effects such as gastrointestinal toxicities (stomatitis, nausea, and abdominal distress), alopecia, bone marrow suppression, and hepatotoxicity [18]. Approximately one third of RA patients discontinue MTX due to toxicity rather than lack of efficacy. Hence, there have been several attempts to develop novel MTX delivery systems in order to overcome these shortcomings. In this regard, nano-sized carriers are promising methods which can selectively deliver therapeutic agents to the inflammatory sites in a controlled or sustained manner [19, 20]. Various nanomaterials including human serum albumin conjugates, chitosan conjugates, liposomal conjugates, or in situ forming hydrogels of polymeric micelles have been suggested $[6,21]$. Our polymeric MNPs also showed the selective delivery to the inflamed site and sustained release of contained drug and exhibited comparable efficacy in a small dosage when irradiated with NIR. These aspects of our MNPs could reduce the concerns about systemic toxicity of MTX. 
Anti-inflammatory action of low-dose MTX for the treatment of RA has been related to the induction of apoptosis in part [22]. Our in vitro studies demonstrated that apoptotic death in RA-FLSs was induced by MTXloaded MNPs and enhanced by NIR irradiation. Because the dose of MTX within MNPs was $0.13 \mu \mathrm{M}$ MTX, MTX-loaded MNPs produced less apoptotic effect, compared with MTX $30 \mu \mathrm{M}$. However, when irradiated with NIR, the apoptotic effect by MTX-loaded MNPs was significantly increased. It is well-known that gold $(\mathrm{Au})$ halfshells strongly absorb NIR light and act as heat carriers [23]. The cytotoxicity of methotrexate is enhanced by increasing the temperature [24], and another in vitro study has shown that MTX release from MTX-loaded gold nanoparticles was temperature-dependent [25]. These results imply that increased temperature of RA-FLSs treated with MNPs upon NIR irradiation may enhance the therapeutic effects of MTX.

In vivo studies using CIA mice revealed that MTXloaded MNPs were delivered to the inflamed paw so that only the inflamed paw could be locally heated using the NIR laser diode. In addition, MTX-loaded MNPs were accumulated in the inflamed paw over an extended time and release of MTX was sustained for at least 3 days. The characteristics of inflamed RA synovium include abundant angiogenesis, abnormal and leaky vasculature, and an influx of inflammatory leukocytes [26]. Because MTX-loaded MNPs are administrated by the intravenous route, they can be more delivered to the hypervascular area (passive targeting). Also, the size of our NPs is attributable to targeted delivery, because 100-115-nmsized nanoparticles are not much eliminated by the spleen and kidney [20]. Another explanation for selective passive targeting and sustained release of these MNPs without further integration of a specific targeting moiety might be due to locally enhanced permeability effects in the inflamed synovium $[27,28]$. In the inflamed joints, rapid angiogenesis and large gaps between endothelial cells of blood vessels lead to selective extravasation of macromolecules. In the normal tissues, macromolecules are cleared rapidly via the lymphatic system, but the clearance of macromolecules in the inflammatory interstitium is relatively impaired that they can remain for a long time. The enhanced permeability effects of PLGA nanoparticle were previously reported in several studies [29].

To confirm the local photothermal effect on MNP of NIR irradiation, body temperatures were measured at different sites and conditions. Body temperatures were increased in the MNP-administrated and NIR-irradiated conditions, and that effect was remarkable in the inflamed area. Using rhodamine-loaded MNPs, we showed prolonged retention for incorporated chemical of MNPs in the NIR-irradiated areas. Therefore, co-application of
MNP and NIR irradiation showed photothermal effect and more release of incorporated MTX, leading to better therapeutic effect in the NIR-irradiated area [30]. Thermotherapy is commonly employed means of nonpharmacological pain management in RA, although its scientific evidence for efficacy has not been strongly proven [31]. In addition, mild heating itself has been shown to decrease the joint stiffness in chronic arthritis [32]. Markovic et al. also demonstrated that short-term hyperthermia suppressed the activation of proinflammatory cytokine in RA-FLSs via blocking the activation of NF-kB [33]. Altogether, the application of NIR irradiation in patients with RA might be expected not only to enhance the therapeutic efficacy of administered MNPs but also to relieve the symptoms associated with inflammatory arthritis.

Our in vivo studies in the CIA mice model clearly showed that administration of MNPs with NIR irradiation (1) ameliorated the clinical signs of arthritis, (2) suppressed serum levels of pro-inflammatory cytokines and anti-CII IgG, and (3) reduced inflammation and prevent bone erosion in the joints despite the low MTX dosage. The therapeutic efficacy of the MNPs was similar to that observed in conventional MTX-treated CIA mice. Treatment with MTX at the same dosage as loading MTX in the MNPs (G3) did not ameliorate arthritis. Administration of MNPs without NIR irradiation was partially effective only during the early period, possibly because the absence of NIR irradiation hampered the sustained release of MTX.

Recently, several studies to investigate nanoparticles containing MTX for the RA treatment have been published. Reported materials include MTX-lipidic nanoemulsion, MTX-polysialic acid-trimethyl chitosan (PSA-TMC) NPs, MTX-superparamagnetic iron oxide PLGA NPs, N-PSA-TMC NPs coated with decoy oligodeoxynucleotides specific to transcription factor NF- $\mathrm{kB}$, and MTX-loaded biodegradable NPs targeting $\mathrm{CD}^{+}{ }^{+}$cells [34-38]. Among them, MTX-lipidic nanoemulsion was developed for intra-articular use, and other NPs were relatively complex to make. Unlike these materials, our MNPs are easy to make and have $\mathrm{Au}$ half-shells for local heating which enable the photothermal treatment.

\section{Conclusions}

In the present study, we demonstrate the synergistic therapeutic effects of MTX-loaded MNPs and photothermal therapy for the treatment of RA. Combined with NIR irradiation, these MTX-loaded MNPs exhibited similar efficacy with a much lower dosage of MTX (approximately 1/1400) without a targeting ligand. Additionally, repetitive dosing with MTX-containing MNPs may enhance the therapeutic effect on arthritis; further 
studies will be required to examine these possibilities. Because of their relatively easy synthesis, low toxicity, and synergistic effect with NIR irradiation, these MNPs could have great potential for the treatment of RA. Furthermore, these MNP systems can be applied with other DMARDs.

\section{Supplementary information}

Supplementary information accompanies this paper at https://doi.org/10. 1186/s13075-020-02230-y.

Additional file 1. Characterization of prepared NPS.

Additional file $\mathbf{2}$ Delivery and accumulation of intravenously injected MTX-loaded MNPS. a Biodistribution of injected MTX-loaded MNPs measured by ICP-MS in major organs and joints ( $n=3$ at each time point). b Ex-vivo NIR absorbance images of injected MTX-loaded MNPs in CIA mice. ${ }^{*} P<0.05$ vs. the 1 day group. Values are expressed as mean $\pm \mathrm{SEM}$ of three mice.

\section{Abbreviations}

RA: Rheumatoid arthritis; DMARDs: Disease-modifying anti-rheumatic drugs; MTX: Methotrexate; NP: Nanoparticle; MNP: Multifunctional nanoparticle; RGD: Arginine-glycine-aspartic acid; PLGA: Poly(DL-lactic-co-glycolic acid); CIA: Collagen-induced arthritis; NIR: Near-infrared; FLS: Fibroblast-like synoviocyte; TEM: Transmission electron microscope; PBS: Phosphatebuffered saline; DAPI: 4', 6'-Diamidino-2-phenylindole; IV: Intravenously; ICPMS: Inductively coupled plasma mass spectrometer; Cll: Type II collagen; IgG: Immunoglobulin G; IL: Interleukin; TNF: Tumor necrosis factor;

ELISA: Enzyme-linked immunosorbent assay; FITC: Fluorescein isothiocyanate; PI: Propidium iodide

\section{Acknowledgements}

We thank MID (Medical Illustration \& Design), a part of the Medical Research Support Services of Yonsei University College of Medicine, for all artistic support related to this work.

\section{Authors' contributions}

YJ Ha and SM Lee were involved in the acquisition and interpretation of data and prepared the initial draft of the manuscript. CH Mun, HJ Kim, Y Bae, $\mathrm{JH}$ Lim, and KY Park carried out the experimental work and interpreted the data. SK Lee participated in the design of the study and underwent critical revision of the manuscript. YB Park and KY Yoo conceived and designed the study, participated in the analysis and interpretation of data, and revised the manuscript. The authors read and approved the final manuscript.

\section{Funding}

This research was supported by a grant from MWH through the Korean Health Technology R\&D Project (Grant No. A110905) and the Korea Health Technology R\&D Project through the Korea Health Industry Development Institute (Grant No. HI14C1324) and from MEST through the National Research Foundation (NRF) of Korea (Grant Nos. NRF-2016R1A2B3011980, NRF-2016R1A2B4014999, and NRF-2012R1A4A1029061).

\section{Availability of data and materials}

The datasets used and/or analyzed during the current study are available from the corresponding author on reasonable request.

\section{Ethics approval and consent to participate}

All animal experiments conformed to the animal welfare guidelines under approved protocols of the Yonsei Institutional Animal Care and Use Committee of Yonsei University, Seoul, Korea. Also, this study was approved by the ethics committee of Yonsei University Severance Hospital (IRB No. 4 2019-0683). All the enrolled patients consent to offer synovial samples and signed written consent.

\section{Consent for publication}

We obtained consent for publication from all the individuals whose synovial samples were given in this manuscript.

\section{Competing interests}

The authors declare that they have no competing interests.

\section{Author details}

${ }^{1}$ Division of Rheumatology, Department of Internal Medicine, Institute for Immunology and Immunologic Diseases, Yonsei University College of Medicine, 50, Yonsei-ro, Seodaemun-gu, Seoul 03722, Republic of Korea. ${ }^{2}$ Nanomedical Graduate Program, Yonsei University, Seoul, Republic of Korea. ${ }^{3}$ Department of Physics, Yonsei University, 50, Yonsei-ro, Seodaemun-gu, Seoul 03722, Republic of Korea.

Received: 14 September 2019 Accepted: 2 June 2020

Published online: 18 June 2020

References

1. Smolen JS, Aletaha D, McInnes IB. Rheumatoid arthritis. Lancet. 2016;388: 2023-38

2. Smolen JS, Landewe R, Bijlsma J, Burmester G, Chatzidionysiou K, Dougados M, Nam J, Ramiro S, Voshaar M, van Vollenhoven $R$, et al. EULAR recommendations for the management of rheumatoid arthritis with synthetic and biological disease-modifying antirheumatic drugs: 2016 update. Ann Rheum Dis. 2017;76:960-77.

3. Gaujoux-Viala C, Smolen JS, Landewe R, Dougados M, Kvien TK, Mola EM, Scholte-Voshaar M, van Riel P, Gossec L. Current evidence for the management of rheumatoid arthritis with synthetic disease-modifying antirheumatic drugs: a systematic literature review informing the EULAR recommendations for the management of rheumatoid arthritis. Ann Rheum Dis. 2010;69:1004-9.

4. Salliot C, van der Heijde D. Long-term safety of methotrexate monotherapy in patients with rheumatoid arthritis: a systematic literature research. Ann Rheum Dis. 2009;68:1100-4.

5. Drosos A. Methotrexate intolerance in elderly patients with rheumatoid arthritis: what are the alternatives? Drugs Aging. 2003;20:723-36.

6. Abolmaali SS, Tamaddon AM, Dinarvand R. A review of therapeutic challenges and achievements of methotrexate delivery systems for treatment of cancer and rheumatoid arthritis. Cancer Chemother Pharmacol. 2013;71:1115-30.

7. Lee SM, Kim HJ, Ha YJ, Park YN, Lee SK, Park YB, Yoo KH. Targeted chemophotothermal treatments of rheumatoid arthritis using gold half-shell multifunctional nanoparticles. ACS Nano. 2013;7:50-7.

8. Toh ML, Hong SS, van de Loo F, Franqueville L, Lindholm L, van den Berg W, Boulanger P, Miossec P. Enhancement of adenovirus-mediated gene delivery to rheumatoid arthritis synoviocytes and synovium by fiber modifications: role of arginine-glycine-aspartic acid (RGD)- and non-RGDbinding integrins. J Immunol. 2005:175:7687-98.

9. Nakayamada S, Saito K, Fujii K, Yasuda M, Tamura M, Tanaka Y. beta1 integrin-mediated signaling induces intercellular adhesion molecule 1 and Fas on rheumatoid synovial cells and Fas-mediated apoptosis. Arthritis Rheum. 2003:48:1239-48.

10. Lee SM, Park H, Choi JW, Park YN, Yun CO, Yoo KH. Multifunctional nanoparticles for targeted chemophotothermal treatment of cancer cells. Angew Chem Int Ed Engl. 2011;50:7581-6.

11. Lee SM, Park H, Yoo KH. Synergistic cancer therapeutic effects of locally delivered drug and heat using multifunctional nanoparticles. Adv Mater. 2010;22:4049-53.

12. Brand DD, Latham KA, Rosloniec EF. Collagen-induced arthritis. Nat Protoc. 2007:2:1269-75

13. Camps M, Ruckle T, Ji H, Ardissone V, Rintelen F, Shaw J, Ferrandi C, Chabert C, Gillieron C, Francon B, et al. Blockade of PI3Kgamma suppresses joint inflammation and damage in mouse models of rheumatoid arthritis. Nat Med. 2005;11:936-43.

14. Arnett FC, Edworthy SM, Bloch DA, McShane DJ, Fries JF, Cooper NS, Healey LA, Kaplan SR, Liang MH, Luthra HS, et al. The American Rheumatism Association 1987 revised criteria for the classification of rheumatoid arthritis. Arthritis Rheum. 1988;31:315-24. 
15. Yoo SA, Park BH, Park GS, Koh HS, Lee MS, Ryu SH, Miyazawa K, Park SH, Cho CS, Kim WU. Calcineurin is expressed and plays a critical role in inflammatory arthritis. J Immunol. 2006;177:2681-90.

16. Nandakumar KS, Svensson L, Holmdahl R. Collagen type II-specific monoclonal antibody-induced arthritis in mice: description of the disease and the influence of age, sex, and genes. Am J Pathol. 2003;163:1827-37.

17. Bannwarth B, Pehourcq F, Schaeverbeke T, Dehais J. Clinical pharmacokinetics of low-dose pulse methotrexate in rheumatoid arthritis. Clin Pharmacokinet. 1996;30:194-210.

18. van Ede AE, Laan RF, Blom HJ, De Abreu RA, van de Putte LB. Methotrexate in rheumatoid arthritis: an update with focus on mechanisms involved in toxicity. Semin Arthritis Rheum. 1998;27:277-92.

19. Pham CT. Nanotherapeutic approaches for the treatment of rheumatoid arthritis. Wiley Interdiscip Rev Nanomed Nanobiotechnol. 2011;3:607-19.

20. Mitragotri S, Yoo JW. Designing micro- and nano-particles for treating rheumatoid arthritis. Arch Pharm Res. 2011;34:1887-97.

21. Dolati S, Sadreddini S, Rostamzadeh D, Ahmadi M, Jadidi-Niaragh F, Yousefi M. Utilization of nanoparticle technology in rheumatoid arthritis treatment. Biomed Pharmacother. 2016;80:30-41.

22. Herman S, Zurgil N, Deutsch M. Low dose methotrexate induces apoptosis with reactive oxygen species involvement in T lymphocytic cell lines to a greater extent than in monocytic lines. Inflamm Res. 2005;54:273-80.

23. Park H, Yang J, Lee J, Haam S, Choi IH, Yoo KH. Multifunctional nanoparticles for combined doxorubicin and photothermal treatments. ACS Nano. 2009;3:2919-26.

24. Hahn GM, Shiu EC. Effect of $\mathrm{pH}$ and elevated temperatures on the cytotoxicity of some chemotherapeutic agents on Chinese hamster cells in vitro. Cancer Res. 1983:43:5789-91.

25. Costa Lima SA, Reis S. Temperature-responsive polymeric nanospheres containing methotrexate and gold nanoparticles: a multi-drug system for theranostic in rheumatoid arthritis. Colloids Surf B Biointerfaces. 2015;133:378-87.

26. Smolen JS, Steiner G. Therapeutic strategies for rheumatoid arthritis. Nat Rev Drug Discov. 2003;2:473-88.

27. Paleolog EM, Fava RA. Angiogenesis in rheumatoid arthritis: implications for future therapeutic strategies. Springer Semin Immunopathol. 1998;20:73-94.

28. Levick JR. Permeability of rheumatoid and normal human synovium to specific plasma proteins. Arthritis Rheum. 1981;24:1550-60.

29. Ishihara T, Kubota T, Choi T, Higaki M. Treatment of experimental arthritis with stealth-type polymeric nanoparticles encapsulating betamethasone phosphate. J Pharmacol Exp Ther. 2009;329:412-7.

30. Rutkowski R, Straburzynska-Lupa A, Korman P, Romanowski W, Gizinska M. Thermal effectiveness of different IR radiators employed in rheumatoid hand therapy as assessed by thermovisual examination. Photochem Photobiol. 2011;87:1442-6.

31. Robinson V, Brosseau L, Casimiro L, Judd M, Shea B, Wells G, Tugwell P. Thermotherapy for treating rheumatoid arthritis. Cochrane Database Syst Rev. 2002;2:Cd002826.

32. Lehmann JF, Warren CG, Scham SM. Therapeutic heat and cold. Clin Orthop Relat Res. 1974;99:207-45.

33. Markovic M, Stuhlmeier KM. Short-term hyperthermia prevents activation of proinflammatory genes in fibroblast-like synoviocytes by blocking the activation of the transcription factor NF-kappaB. J Mol Med (Berl). 2006;84:821-32.

34. Wardwell PR, Forstner MB, Bader RA. Investigation of the cytokine response to NF-kappaB decoy oligonucleotide coated polysaccharide based nanoparticles in rheumatoid arthritis in vitro models. Arthritis Res Ther. 2015;17:310.

35. Zhang N, Wardwell PR, Bader RA. In vitro efficacy of polysaccharide-based nanoparticles containing disease-modifying antirheumatic drugs. Pharm Res. 2014;31:2326-34.

36. Moura CC, Segundo MA, Neves J, Reis S, Sarmento B. Co-association of methotrexate and SPIONs into anti-CD64 antibody-conjugated PLGA nanoparticles for theranostic application. Int J Nanomedicine. 2014;9:4911-22.

37. Mello SB, Tavares ER, Bulgarelli A, Bonfa E, Maranhao RC. Intra-articular methotrexate associated to lipid nanoemulsions: anti-inflammatory effect upon antigen-induced arthritis. Int J Nanomedicine. 2013;8:443-9.

38. Colombo F, Durigutto P, De Maso L, Biffi S, Belmonte B, Tripodo C, Oliva R Bardini P, Marini GM, Terreno E, et al. Targeting CD34(+) cells of the inflamed synovial endothelium by guided nanoparticles for the treatment of rheumatoid arthritis. J Autoimmun. 2019;103:102288.

\section{Publisher's Note}

Springer Nature remains neutral with regard to jurisdictional claims in published maps and institutional affiliations.

\section{Ready to submit your research? Choose BMC and benefit from}

- fast, convenient online submission

- thorough peer review by experienced researchers in your field

- rapid publication on acceptance

- support for research data, including large and complex data types

- gold Open Access which fosters wider collaboration and increased citations

- maximum visibility for your research: over $100 \mathrm{M}$ website views per year

At BMC, research is always in progress.

Learn more biomedcentral.com/submissions 